Journal of Social Sciences 5 (4): 355-361, 2009

ISSN 1549-3652

(C) 2009 Science Publications

\title{
The Relationship between School, Class and Co-Curriculum Absenteeism on the Academic Performance of Selected Secondary School
}

\author{
${ }^{1}$ Azizi Yahaya, ${ }^{1}$ Jamaludin Ramli, ${ }^{1}$ Shahrin Hashim, ${ }^{2}$ Mohd. Ali Ibrahim and ${ }^{3}$ Zurihanmi Zakaria \\ ${ }^{1}$ Department of Foundation Education, Faculty of Education, \\ Universiti Teknologi Malaysia, 81310 UTM Skudai Johor Malaysia \\ ${ }^{2}$ Department of Mathematics and Science, Faculty of Education, \\ University Technology Malaysia, 81310 UTM Skudai Johor Malaysia \\ ${ }^{3}$ Ministry of Youth and Sport, Putrajaya
}

\begin{abstract}
Problem statement: The purpose of this study is to identify the relationship between causes of truant, types of truant and activities done during truant against academic achievement among the lower secondary students. Approach: The research instrument used in this study was questionnaire with Likert scale. The respondents for this study were 80 students were randomly chosen as respondents through simple random sampling. The data collected was analyzed by using the Statistical Package for Social Science for Windows (SPSS 11.5). Inferential and descriptive statistics is used to find the mean, frequency and standard deviation. Results: The findings showed that activities done during truant such as helping the family, joining the negative groups, crime is at the low level and working part-time together with loafing are at the medium level. Findings also showed there is no significance relationship between friends, parents, do not like the teacher, do not like the subject and homework with academic achievement and there is significance relationship between family problems with academic achievement. Conclusion: Parents must also pay due attention and control over their children social life to avoid them from picking up the habit of playing truant from school.
\end{abstract}

Key words: Academic achievement, truant, activities, family problems

\section{INTRODUCTION}

Students are the future leader to the country. Their activities have been the hot topics of discussions and were given warm attention from the whole society. Mass media often broadcast many news and stories about the hoax of the students and various social problems that surrounded them. Social problems and criminal acts involving students are coming to an alarming state. At student stage, an individual experiences a very rapid change, either physically, emotionally or socially ${ }^{[1]}$.

The students' notoriousness are not only confined to smoking cigarettes, fighting with each other or behaving obscenely, but also involving dumping babies, school absenteeism, running away from home, free sex and mingling. Now they even dare to commit serious criminal acts such joining bad syndicate and become gangsters, murder, with or without firearm burglar, rape, prostitution, gambling, vandalism, drug abuse, alcoholic, pornography and so forth as the main activity when they are playing truant ${ }^{[2]}$. Problems such as these not only happen in town and urban schools, but also take place in the rural schools. Students who often violate discipline or misbehave in schools are referred as deviant students.

Movement of students from one class to another class provides some of the students the opportunity not to go to the class and this give pleasure to the students and eventually make them dare to play truant. Absenteeism among school students often apply to students of non-working mothers ${ }^{[2]}$. The schools' management that in overcoming this problem, efforts should be made to ensure schools become enjoyable places for their students ${ }^{[3]}$. In addition, the intimate relationship between teachers and students, facilities that encourage their attendance to school and concerns from parents and community could well be the factors that may solve the problem.

There are many other factors that contribute to school absenteeism. That school absenteeism is not only caused by the "incompetent of teacher as claimed"

Corresponding Author: Azizi Yahaya, Department of Foundation Education, Faculty of Education,

University Technology Malaysia, 81310 UTM, Skudai Johor, Malaysia

Tel: +60127570298 Fax: +607550542 
and the lay out period of useful activities after examinations season ${ }^{[4]}$. Absenteeism is one of the discipline problems that have become more unbecoming in schools. More and more primary and secondary students are inclined to play truant. Busy working parents do not have much time for their children. Are parents going to be held as the main factor for the existence of school absenteeism problem? Do not be surprised if there is school absenteeism driven by their parents themselves, especially those students who are from the primary schools. This is especially obvious on additional classes on Saturdays and after examinations. The poor attendance could be seen when students from a few classes are combined into one for facilitating teaching purpose. Isn't it the attitude of some of the parents who encourage their children not to attend school has given an unhealthy teaching to their own children? Later in the secondary the students themselves will find various reasons that may excuse them from attending schools. Eventually, they would find that going to school is a burden. These students will then begin to plan with friends to stay away from school and resort to deviant and lingering at other places.

Students who do not have any self-awareness will perform criminal activity and begin to violate school rules in a way to show their aggressive attitude. The question is, if the parents are responsible to mould the character and behavior of their children, why does the student discipline problem still exist in the school surroundings? The attitudes of children and destructive family surroundings may not be restored if they do not get assistance from the responsible parties ${ }^{[5]}$. Therefore, a study was carried out with the aims to identify what are the causes of school absenteeism, types of absenteeism and activities that take place at the time of absenteeism and its influence on the students' academic achievement.

\section{MATERIAL AND METHODS}

This study utilized surveying methodology. It was aimed at identifying absenteeism problems that were happening in the secondary schools. Review is only conducted with the objective to get as clear a pattern, something about the widespread phenomenon ${ }^{[6]}$. The results obtained were of high validity and reliability because the social behavior polar could not change drastically.

The method used in data collection from the respondents was through questionnaire. This method was used because it saved the time of collecting the data in a short period of time. The questionnaire consisted of 4 parts, that is Part A, B, C and D. Part A consisted of questions about the background of students, Part B consisted questions regarding the causes of absenteeism, Part $\mathrm{C}$ consisted questions about types of absenteeism and Part $\mathrm{D}$ were questions concerning the activities undertaken at the time of absenteeism. Data collected from the questionnaire would be analyzed by using the Statistical Package for Social Science for Windows (SPSS 11.5).

There are two types of analysis that is descriptive analysis and inference analysis ${ }^{[7]}$. Descriptive analysis is mean, t-test, percentage, frequency and also the standard deviation. Whereas inference analysis is Pearson correlation. In this study, the data were analyzed by using descriptive analysis of mean, standard deviation, percentage and frequency. In addition, inference analysis Pearson correlation was also used in the study to test the hypothesis.

\section{Result of study:}

Factors that influences in school absenteeism: Table 1 shows that the item 'I played truant because of friend's invitation' has the highest mean score of and standard deviation 0.501. A number of 36 respondents which is $45 \%$ agreed with this item, whereas 44 respondents equivalent to $55 \%$ absolutely agree with this item. No respondents who are absolutely not agreed, not agreed and not sure with this item.

The overall mean is 2.8900 whereas the overall standard deviation is 0.46104 . This shows that the academic achievement is at the average level.

Table 2 shows respondents distribution based on percentage, mean and standard deviation for the cause of parents. Result of study shows that the item 'I played truant because my parents did not bother about me' has the highest mean score of 3.69 and standard deviation 1.014. Only one respondent which is $1.3 \%$ absolutely disagreed with this item whereas a number of 16 respondents which are $20 \%$ not agreed with this item.

Table 1: Respondents distribution based on frequency, percentage, mean and standard deviation for cause of influence of peers

\begin{tabular}{|c|c|c|c|c|c|c|c|}
\hline Item & ANA & NA & NS & A & AA & Mean & SD \\
\hline I played truant because of friend's invitation & $0(0.0)$ & $0\left(\begin{array}{lll}0 & 0\end{array}\right)$ & $0(0.0)$ & $36(45.0)$ & $44(55.0)$ & 4.55 & 0.501 \\
\hline I played truant because I was being bullied by friends & $10(12.5)$ & $40(50.0)$ & $14(17.5)$ & $16(20.0)$ & $0(0.0)$ & 2.45 & 0.953 \\
\hline I played truant because I was being threatened by friends & $2(2.5)$ & $46(57.5)$ & $16(20.0)$ & $16(20.0)$ & $0(0.0)$ & 2.58 & 0.839 \\
\hline
\end{tabular}

Overall mean = 2.8900; Overall standard deviation = 0.46104; ANA: Absolutely Not Agreed, NA: Not Agreed, NS: Not Sure, A: Agreed, AA: Absolutely agreed 


\section{J. Social Sci., 5 (4): 355-361, 2009}

Table 2: Respondents distribution based on frequency, percentage, mean and standard deviation for cause of parents

\begin{tabular}{|c|c|c|c|c|c|c|c|}
\hline Item & ANA & NA & NS & A & $\mathrm{AA}$ & Mean & $\mathrm{SD}$ \\
\hline I pla & $15(18.8)$ & $49(6$ & $5(6.3)$ & $11(13.8)$ & $0(0$ & 2.15 & 0.887 \\
\hline e my parents & $3(3.8)$ & 22( & 0( & $45(56.3)$ & $10(12.5)$ & 3.46 & 1.136 \\
\hline I played truant because my parents often absent from work & $17(21.3)$ & $52(65.0)$ & $3(3.8)$ & $6(7.5)$ & $2(2.5)$ & 2.05 & 0.884 \\
\hline
\end{tabular}

Overall mean $=2.6350$; Overall standard deviation $=0.37757$

Table 3: Respondents distribution based on frequency, percentage, mean and standard deviation for cause of disliking the teachers

\begin{tabular}{|c|c|c|c|c|c|c|c|}
\hline Item & ANA & NA & $\mathrm{NS}$ & $\mathrm{A}$ & $\mathrm{AA}$ & Mean & $\mathrm{SD}$ \\
\hline I played truant because the teachers were fierce & $0(0.0)$ & $23(28.8)$ & $1(1.3)$ & $41(51.3)$ & $15(18.8)$ & 3.60 & 1.098 \\
\hline I played truant because the teachers canned pupils & $0.0(0.0)$ & $22.0(27.5)$ & $4.0(5.0)$ & $44.0(55.0)$ & $10.0(12.5)$ & 3.53 & 1.031 \\
\hline I played because the teachers absented often & $4(5.0)$ & $39(48.8)$ & $3(3.8)$ & $25(31.3)$ & $9(11.3)$ & 2.95 & 1.211 \\
\hline
\end{tabular}

Overall mean $=2.9100 ;$ Overall standard deviation $=0.43621$

Table 4: Respondents distribution based on frequency, percentage, mean and standard deviation for cause of disliking the subjects

\begin{tabular}{|c|c|c|c|c|c|c|c|}
\hline Item & ANA & NA & NS & A & AA & Mean & SD \\
\hline I played truant because did not like certain subjects & $16(20.0)$ & $33(41.3)$ & $0(0.0)$ & $23(28.8)$ & $8(10.0)$ & 2.68 & 1.348 \\
\hline I played truant because did not like to remember & $3(3.8)$ & $32(40.0)$ & $6(7.5)$ & $35(43.8)$ & $4(5.0)$ & 3.06 & 1.095 \\
\hline I played truant because everyday learned the same subjects & $25(31.3)$ & $38(47.5)$ & $1(1.3)$ & $139(16.3)$ & $3(3.8)$ & 2.14 & 1.145 \\
\hline
\end{tabular}

$\frac{\text { I played truant because everyday learned the same subjects }}{\text { Overall mean }=2.8125 ; \text { Overall standard deviation }=0.51346}$

Table 5: Respondents distribution based on frequency, percentage, mean and standard deviation for cause of homework

\begin{tabular}{|c|c|c|c|c|c|c|c|}
\hline Item & ANA & NA & NS & A & AA & Mean & SD \\
\hline I played truant because a lot of homework & $5(6.3)$ & $24(30.0)$ & $2(2.5)$ & $39(48.8)$ & $10(12.5)$ & 3.31 & 1.208 \\
\hline I played truant because a lot of difficult homework & $9(11.3)$ & $37(46.3)$ & $8(10.0)$ & $20(25.0)$ & $6(7.5)$ & 2.71 & 1.182 \\
\hline I played truant because there was no one to guide me on doing homework & $10(12.5)$ & $39(48.8)$ & $5(6.3)$ & $22(27.5)$ & $4(5.0)$ & 2.64 & 1.161 \\
\hline
\end{tabular}

Overall mean $=3.0250$; Overall standard deviation $=0.48509$

A number of 3 respondents which are $3.8 \%$ are not sure with this item. Forty seven respondents which are $58.8 \%$ agreed with this item. Thirteen respondents which are $16.3 \%$ highly agreed with this item.

The overall mean is 2.63 and standard deviation is 0.38 . This shows that the academic achievement is at the average level.

Table 3 shows the respondents distribution based on percentage, mean and standard deviation for the cause of disliking teachers. Result of study shows that the item 'I played truant because of fierce teachers' has the highest mean score of 3.60 and standard deviation 1.098. A number of 23 respondents which are $28.8 \%$ not agreed with this item. One respondent which is $1.3 \%$ was not sure with this item. A number of 41 respondents which are $51.3 \%$ agreed with this item while 15 respondents which is $18.8 \%$ absolutely agreed with this item. There was no respondent who absolutely not agreed with this item.

The overall mean is 2.9100 and standard deviation is 0.43621 . This shows that the academic achievement is at the average level.

Table 4 shows the respondents distribution based on percentage, mean and standard deviation for the cause of disliking the subjects. Result of study shows that the item 'I played truant because there were less practical work' has the highest mean score of 3.21 and standard deviation 1.166. A number of 6 respondents which is $7.5 \%$ absolutely disagreed with this item, whereas 22 respondents which are $27.5 \%$ not agreed with this item. Eight respondents which are $10 \%$ were not sure with this item. A number of 37 respondents which is $46.3 \%$ agreed with this item. Seven respondents which are $8.8 \%$ absolutely agreed with this item.

The overall mean is 2.81 and standard deviation is 0.51 . This shows that the academic achievement is at the average level.

Table 5 shows the respondents distribution based on percentage, mean and standard deviation for the cause of doing homework. Result of study shows that the item 'I played truant because there were less practical work' has the highest mean score of 3.31 and standard deviation 1.208. A number of 5 respondents which are $6.3 \%$ absolutely not agreed with this item, whereas 24 respondents which are $27.5 \%$ not agreed with this item. Two respondents which are $2.5 \%$ were not sure with this item. A number of 39 respondents which is $48.8 \%$ agreed with this item. Ten respondents which are $12.5 \%$ absolutely agreed with this item.

The overall mean is 3.0250 and standard deviation is 0.48509 . This shows that the academic achievement is at the average level.

Table 6 shows the respondents distribution based on percentage, mean and standard deviation for the cause of doing homework. Result of study shows that the item 'I played truant because fighting with my siblings' has the highest mean score of 4.20 and standard deviation 0.770 . There was no respondent absolutely not agreed with this item. A number of 5 


\section{J. Social Sci., 5 (4): 355-361, 2009}

Table 6: Respondents distribution based on frequency, percentage, mean and standard deviation for cause of family

\begin{tabular}{|c|c|c|c|c|c|c|c|}
\hline Item & ANA & NA & NS & A & AA & Mean & SD \\
\hline I played truant because my family members often & $16(20.0)$ & $58(72.5)$ & $2(2.5)$ & $4(5.0)$ & $0(0.0)$ & 1.93 & 0.652 \\
\hline I played truant because of financial problem & $16(20.0)$ & $22(27.5)$ & $0(0.0)$ & $28(35.0)$ & $14(17.5)$ & 3.03 & 1.467 \\
\hline I played truant because quarreling with my siblings & $0(0.0)$ & $5(6.3)$ & $2(2.5)$ & $45(56.3)$ & $28(35.0)$ & 4.20 & 0.770 \\
\hline
\end{tabular}

Overall mean $=2.6050 ;$ Overall standard deviation $=0.47731$

Table 7: Respondents distribution based on frequency, percentage, mean and standard deviation for the activity of doing part-time job

\begin{tabular}{|c|c|c|c|c|c|c|c|}
\hline Item & ANA & NA & NS & A & AA & Mean & SD \\
\hline I played truant because I worked at shopping centre & $8(10.0)$ & $20(25.0)$ & $0(0.0)$ & $36(45.0)$ & $16(20.0)$ & 3.40 & 1.327 \\
\hline I played truant because I worked at food stall & $23(28.8)$ & $50(62.5)$ & $0(0.0)$ & $7(8.8)$ & $0(0.0)$ & 1.89 & 0.795 \\
\hline I played truant because I worked at sundry shop & $33(41.3)$ & $44(55.0)$ & $0(0.0)$ & $3(3.8)$ & $0(0.0)$ & 1.66 & 0.674 \\
\hline
\end{tabular}

Overall mean = 2.3800; Overall standard deviation $=0.40827$

Table 8: Respondents distribution based on frequency, percentage, mean and standard deviation for helping the family

\begin{tabular}{|c|c|c|c|c|c|c|c|}
\hline Item & ANA & NA & NS & A & AA & Mean & SD \\
\hline I helped my family & $0(0.0)$ & $4(5.0)$ & $3(3.8)$ & $53(66.3)$ & $20(25.0)$ & 4.11 & 0.693 \\
\hline I took care of my siblings & $16(20.0)$ & $36(45.0)$ & $2(2.5)$ & $17(21.3)$ & $9(11.3)$ & 2.59 & 1.328 \\
\hline I took care of my unwell family & $9(11.3)$ & $30(37.5)$ & $0(0.0)$ & $35(43.8)$ & $6(7.5)$ & 2.99 & 1.258 \\
\hline
\end{tabular}

Overall mean: 2.3438; Overall standard deviation: 0.41026

respondents which is $6.3 \%$ not agreed with this item. Two respondents which are $2.5 \%$ were not sure with this item. A number of 45 respondents which is $56.3 \%$ agreed with this item. A number of 28 respondents which is $35.0 \%$ absolutely agreed with this item.

The overall mean is 2.6050 and standard deviation is 0.47731 . This shows that the academic achievement is at the average level.

Types of absenteeism in schools: There are 3 types of absenteeism that have been done by the respondents in this study namely school absenteeism, class absenteeism and Co-Curriculum absenteeism. The result of this study shows that a number of 64 respondents which is $80 \%$ never play truant school and 16 respondents which is $20.0 \%$ had never been schooling. Meanwhile 28 respondents whish is $35 \%$ had played truant to class and 52 respondents which is $65 \%$ had never been to class. The result of this study also shows that a number of 10 respondents which is $13 \%$ had never played truant to Co-Curriculum and 70 respondents which is $87 \%$ had never attended CoCurriculum.

The main activities undertaken by the students at the time of absenteeism.

Table 7 shows the respondents distribution based on percentage, mean and standard deviation for the cause of doing part-time job. Result of study shows that the item 'I worked in the fast food restaurant' has the highest mean score of 3.43 and standard deviation 1.230. A number of 4 respondents which are $5.0 \%$ absolutely not agreed with this item, whereas 24 respondents which are $30.0 \%$ not agreed with this item. There was no respondent not sure with this item. A number of 38 respondents which are $47.5 \%$ agreed with this item. A number of 14 respondents which are $17.5 \%$ absolutely agreed with this item.

The overall mean is 2.3800 whereas the standard deviation is 0.40827 . This shows that the academic achievement is at the average level.

Table 8 shows the respondents distribution based on percentage, mean, standard deviation for activities to help family. Based on the search, 'I played truat because I helped my family by collecting recyclable things' shows the highest mean score of 4.14 and standard deviation is 0.791 . No respondent was 'absolutely not agreed' with this items. Six respondents which are $7.5 \%$ were 'not agreed' with it. Two respondents which are $2.5 \%$ were 'not sure' with this item. Three respondents which are 3.8\% 'Agreed' with this item. 47 respondents which is $58.8 \%$ agreed with this items meanwhile 25 respondent which is $31.3 \%$ 'Absolutely agreed'.

The overall mean is 2.34 whereas the standard deviation is 0.41 . This shows that the academic achievement is at average level.

Table 9 shows respondent distribution on percentage, mean and standard deviation for mingle activity. Based on the study, 'Mingle in shopping complex' shows the highest mean which is 3.74 and standard deviation is 1.156 . Three respondents which are 3.8 percent absolutely not agreed with this item and 16 respondents which are $20 \%$ not agreed. No respondent voted for 'not sure'. Forty one respondents which are $51.3 \%$ agreed. 20 respondents which are $25 \%$ absolutely agreed.

The overall mean is 2.97 while standard deviation is 0.60 . This concludes that the academic achievement is at average level. 
Table 9: Respondents distribution based on frequency, percentage, mean and standard deviation for mingling activities

\begin{tabular}{llllllll}
\hline Item & ANA & NA & NS & A & AA & Mean & SD \\
\hline Mingle at shopping complex & $3(3.8)$ & $16(20.0)$ & $0(0.0)$ & $41(51.3)$ & $20(25.0)$ & 3.74 & 1.156 \\
Just round in town & $9(11.3)$ & $25(31.3)$ & $2(2.5)$ & $42(52.5)$ & $2(2.5)$ & 3.04 & 1.185 \\
Playing games at cyber cafe & $7(8.8)$ & $12(15.0)$ & $0(0.0)$ & $43(53.8)$ & $18(22.5)$ & 3.66 & 1.232 \\
\hline
\end{tabular}

Overall mean: 2.97; Overall standard deviation: 0.602

Table 10: Respondents distribution based on frequency, percentage, mean and standard deviation for involvement in negative group

\begin{tabular}{|c|c|c|c|c|c|c|c|}
\hline Item & ANA & NA & NS & A & $\mathrm{AA}$ & Mean & SD \\
\hline Involved in secret society & $36(45.0)$ & $44(55.0)$ & $0(0.0)$ & $0(0.0)$ & $0(0.0)$ & 1.55 & 0.501 \\
\hline Involved in gangsters & $34(42.5)$ & $41(51.3)$ & $4(5.0)$ & $1(1.3)$ & $0(0.0)$ & 1.65 & 0.638 \\
\hline Involved in 'Along' group & $40(50.0)$ & $40(50.0)$ & $0(0.0)$ & $0(0.0)$ & $0(0.0)$ & 1.50 & 0.503 \\
\hline
\end{tabular}

Overall mean: 1.69; Overall standard deviation: 0.314

Table 11: Respondents distribution based on frequency, percentage, mean and standard deviation for criminal acts

\begin{tabular}{|c|c|c|c|c|c|c|c|}
\hline Item & ANA & NA & NS & $\mathrm{A}$ & AA & Mean & SD \\
\hline Destroying public property & $43(53.8)$ & $31(38.8)$ & $6(7.5)$ & $0(0.0)$ & $0(0.0)$ & 4.51 & 0.799 \\
\hline Raping & $36(45.0)$ & $44(55.0)$ & $0(0.0)$ & $0(0.0)$ & $0(0.0)$ & 4.24 & 0.501 \\
\hline Gambling & $23(28.8)$ & $48(60.0)$ & $0(0.0)$ & $9(11.3)$ & $0(0.0)$ & 1.94 & 0.862 \\
\hline Illegal racing & $0(0.0)$ & $12(15.0)$ & $0(0.0)$ & $45(56.3)$ & $23(28.8)$ & 4.53 & 0.948 \\
\hline Drug traking & $43(53.8)$ & $37(46.3)$ & $0(0.0)$ & $0(0.0)$ & $0(0.0)$ & 4.46 & 0.502 \\
\hline Drug distributing & $34(42.5)$ & $45(56.3)$ & $1(1.3)$ & $0(0.0)$ & $0(0.0)$ & 4.16 & 0.636 \\
\hline
\end{tabular}

Overall mean: 1.7828; Overall standard deviation: 0.32054

Table 12: Correlation analysis between selected variables with academic achievement

\begin{tabular}{lcl}
\hline & Academic achievement & \\
& Pearson correlation & Sig. (2-tailed) \\
\hline Peers & 0.152 & 0.180 \\
Parents & -0.049 & 0.667 \\
Disliking teacher & -0179.000 & 0.111 \\
Disliking subject & 0.010 & 0.927 \\
Doing house work & -0.150 & 0.184 \\
Family problems & -0.258 & 0.021 \\
School absenteeism & 0.161 & 0.154 \\
Class absenteeism & 0.254 & 0.023 \\
Co-curriculum absenteeism & 0.122 & 0.282 \\
\hline
\end{tabular}

*Correlation is significant at the 0.05 level (2-tailed)

Table 10 shows the respondents distribution according to percentage, mean and standard deviation for involving in negative group. Based on the search, 'Involved in Mat Rempit' shows the highest mean which is 2.00 and standard deviation 1.067. A number of 30 respondents which are $37.5 \%$ 'absolutely not agreed'. Meanwhile, 35 respondents which are $43.8 \%$ not agreed with this item. A number of 15 respondents which are $18.8 \%$ agreed with it. No respondent was not sure and absolutely agreed with this item.

The over all mean is 1.69 while standard deviation is 0.31 . This shows that academic achievement is at the average level.

Table 11 shows respondents distribution according percentage, mean and standard deviation for criminal act. Based on search, 'Illegal racing' shows highest mean which is 4.53 and standard deviation is 0.948 . A number of 12 respondents which are $15 \%$ not agreed with this item. A number of 456 respondents which are $56.3 \%$ agreed while 23 respondents with $28.8 \%$ absolutely agreed with this item. No respondents were 'Absolutely not agreed' and 'Not sure' with it.

'Gambling' has the lowest mean score which is 1.94 with standard deviation 0.862 . A number of 23 respondents which are $28.8 \%$ absolutely not agreed with this item whereas 48 respondents which are $60 \%$ not agreed with this item. Nine respondents which are $11.3 \%$ agreed with this item. No respondent was 'not sure' and 'absolutely agreed' with this item.

The overall mean is 1.7828 while the standard deviation is 0.32054 . This shows that the academic achievement is at average level.

Table 12 shows correlation analysis between selected variables with academic achievement. From the aspect of peer group, $r=0.152$. This shows that the relationship between causes of peers with academic achievement is very low. $p=0.180>0.05$. So hypothesis Nol is accepted and there is no significant relationship between the causes of the peers with academic achievement

In parents it shows that $\mathrm{r}=-0.0491$ the relationship between parents with academic achievement is very low. When $\mathrm{p}=0.667>0.05$. So hypothesis Nol is accepted and there is no significant relationship between causes of parents with academic achievement. The relationship between causes of parents with academic achievement is reciprocal.

In Disliking Teacher shows that $r=-0.179$. This shows the relationship between disliking the teachers with academic achievement is very low 


\section{J. Social Sci., 5 (4): 355-361, 2009}

when $p=0.111>0.05$. So hypothesis Nol is accepted and there is no significant relationship between the disliking the teachers with academic achievement. The relationship between disliking the teachers with academic achievement is reciprocal.

In disliking the subjects $r=0.010$. This shows that the relationship between disliking the subjects with academic achievement is very low when $\mathrm{p}=0.927>0.05$. So hypothesis Nol is accepted and there is no significant relationship between the disliking the subjects with academic achievement.

In house work $\mathrm{r}=-0.150$. This shows that the relationship between doing house work with academic achievement is very low when $\mathrm{p}=0.184>0.05$. So hypothesis Nol is accepted and there is no significant relationship between doing house work with academic achievement. The relationship between doing house work house with academic achievement is reciprocal.

In family problems $r=-0.258$. This shows that the relationship between family problems with academic achievement is weak where $\mathrm{p}=0.021<0.05$. Hypothesis Nol is rejected and there is a significant relationship between family problems with academic achievement. The relationship between the family problems with academic achievement is reciprocal.

In school absenteeism $r=0.161$. This shows that the relationship between school absenteeism with academic achievement is very low when $\mathrm{p}=0.154>0.05$. So hypothesis Nol is accepted and there is no significant relationship between school absenteeism with academic achievement.

In class absenteeism $r=0.254$. This shows that the relationship between class absenteeism with academic achievement is weak, when $p=0.023<0.05$. Hypothesis Nol is rejected and there is a significant relationship between class absenteeism with academic achievement.

Co-Curriculum absenteeism $r=0.122$. This shows that the relationship between Co-Curriculum absenteeism with academic achievement is very low when $\mathrm{p}=0.282>0.05$. So hypothesis Nol is accepted and there is no significant relationship between CoCurriculum absenteeism with academic achievement.

\section{DISCUSSION}

Overall, 'doing homework' is at an average level. This is similar with ${ }^{[8]}$, who cited that the influence of peers, drug abuse, bully, bored, dislike some of the teachers, trying to skip from exam and unstable family, all contributes to absenteeism problems in school. As a whole, these three types of truants are at the lower level. This is very similar to report ${ }^{[9]}$ which noticed missing from the class and truant in school comprises the highest percentage of students' misconduct among the students. The Education Ministry's target towards 'Zero Defect' will never achieve if both these problems are not solved immediately. This finding is identical to ${ }^{[10]}$ which said that the latest number of students who involved in truant problems is 34628 students.

Overall, 'doing part-time job' and 'mingling' are at the moderate level. Whereas helping the family and taking part in criminal activities and joining bad groups are still at the lower level. Based on study ${ }^{[3]}$, most of the students who played truant loved wasting their time by going to entertainment places. Students who played truant would be left behind in study and worst of all, some of them might instead involved in negative activities such as drug abuse, vandalism, gangsters, gambling, mingling, alcoholism and free $\operatorname{se}^{[11]}$.

Recommendation: Based on the result, discussion and review that have been made, the researcher has some suggestion to put forward:

- The result shows that disliking the teachers makes truant in low level. Thus, teachers are advised to try to study about as reason to play truant is at moderate level. Therefore, teachers have to understanding the socio-economy and family background of the students in order to know the factors that influenced them. This may be able to help the teachers in understanding the failure or the behavior of the student who played truant. Teachers who are considerable should give reasonable amount of homework based on students' learning level so that the students can complete the work well

- The study also shows that parents are also the main reason that leads to absenteeism problems among students. Thus parents should get together with teachers to overcome the absenteeism problem by organizing more short or long courses to increase parental knowledge

- The result of this study also found that school, class and co-curriculum absenteeism are on the low level. However, the best way to overcome these problems is to stricken the school rules. Severe punishment such as suspension and expulsion from school should been taken against undisciplined students

- In mingling activities parents should pay more attention to their children in schools and spend more time with them as possible. Parents must also pay due attention and control over their children 
social life to avoid them from picking up the habit of playing truant from school

\section{CONCLUSION}

In conclusion, all parties should give their cooperation in order to make the dream comes true. Drastic steps should be taken if we are to produce a new and useful generation. Action from one party alone will never make a difference, as such we must stand and work together in order to overcome this problem.

\section{ACKNOWLEDGEMENT}

The researchers would like to thank MOSTIC, Research Management Centre (RMC) and University Technology Malaysia. The researchers also wish to thank lecturers and friends for many helpful ideas and discussion.

\section{REFERENCES}

1. R. J. Stiggins, 1997. Student Centered Classroom Measurement, Prentice Hall, New Jersey. ISBN: 10: 0130225371.

2. Yahaya, A. Y. Boon, J. Ramli, N. Yahaya and R. R. Rahman, 2009. The relationship between dimensions of personality, self concept and family influence on students in the FELDA scheme in Johore Malaysia. Eur. J. Soc. Sci., 11. ISSN: 1450-2267

3. Abu Samah, A. and R. Baharudin, 2002. Disiplin Pelajar Sekolah Rendah, UPM Publication, Serdang, pp: 22-27. ISSN: 1394-1801

4. Lagerspetz, K.M.J., K. Bjorqvist and T. Peltonen, 1988. Is indirect aggression more typical of females? Gender differences in aggressiveness in 11- to 12-year-old children. Aggress. Behav., 14: 403-414.

http://www3.interscience.wiley.com/journal/11241 6575/abstract?CRETRY $=1 \&$ SRETRY $=0$
5. Gumpel, T.P. and H. Meadan, 2000. Children's perception of school-based violence. Br. J. Educ. Psychol., 70: 391-404. http://www.ncbi.nlm.nih.gov/pubmed/11059118

6. Mohd Najib Abd Ghafar, 2003. Rekabentuk Tinjauan Soal Selidik Pendidikan. Penerbit University Technology Malaysia, Skudai, Johor, ISBN: 983-62-0310-5.

7. Azizi Yahaya, Yusof Boon and Shahrin Hashim, 2005. Social Psychology of Adoloscent Pahang: PTS Publication and Distributors Sdn. Bhd. ISBN: 978-983-3585-39-7

8. Azizi Yahaya, Shahrin Hashim, Jamaludin Ramli, Yusof Boon and Abdul Rahim Hamdan, 2007. Mastering in Research Method. PTS Publications and Distribution Sdn Bhd., Kuala Lumpur, ISBN 983-3585-83-3.

9. Trump, K.S., 1999. Scared or prepared: Reducing risks with school security assessments. High School Mag., 6: 18-23. http://eric.ed.gov/ERICWebPortal/custom/portlets/ recordDetails/detailmini.jsp?_nfpb=true\&_\&ERIC ExtSearch_SearchValue_0=EJ587589\&ERICExtS earch_SearchType_0=no\&accno=EJ587589

10. Domjan, M.P., 2002. The Principles of Learning and Behavior. 5th Edn., Wodsworth Publishing/Thomson Learning, USA., ISBN: 10: 053456156X, pp: 480.

11. J/G Bachman, 1970. Droping Out: Problems of Symptoms. University Press, Michigan, pp: 33-37. 